\title{
Optimization of enzymatic hydrolysis of Pleurotus ostreatus derived proteins through RSM and evaluation of nutritional and functional qualities of mushroom protein hydrolysates
}

\section{Otimização da hidrólise enzimática de proteínas derivadas de P. ostreatus por meio de Metodologia de Superfície de Resposta e avaliação de qualidade nutricional e funcional de hidrolisados da proteína do cogumelo}

\author{
Bhaswati Goswami ${ }^{1}$, Sayari Majumdar ${ }^{1}$, Ruma Dutta1 ${ }^{1}$, Jayati Bhowal'* (D) \\ ${ }^{1}$ Indian Institute of Engineering Science and Technology, School of Community Science \& Technology, West Bengal \\ - India
}

${ }^{*}$ Corresponding Author: Jayati Bhowal, Indian Institute of Engineering Science and Technology, School of Community Science \& Technology, Shibpur. P. O. Botanic Garden, Howrah, 711103, West Bengal - India, e-mail: jayatibhowal@gmail.com

Cite as: Goswami, B., Majumdar, S., Dutta, R., \& Bhowal, J. (2022). Optimization of enzymatic hydrolysis of Pleurotus ostreatus derived proteins through RSM and evaluation of nutritional and functional qualities of mushroom protein hydrolysates. Brazilian Journal of Food Technology, 25, e2020186. https://doi.org/10.1590/1981-6723.18620

\begin{abstract}
Pleurotus ostreatus (Jacq.) P. Kumm., the second most widely cultivated oyster mushroom was grown on paddy straw, which is cheap and readily available waste material. After harvesting and drying, nutritional, and antinutritional composition of $P$. ostreatus were estimated using the standard assay methods. Tannin and phytic acid were present in very negligible amount $(0.095 \pm 0.027 \mathrm{mg} / \mathrm{g}$ and $0.150 \pm 0.083 \mathrm{mg} / \mathrm{g}$, respectively), whereas oxalate and cyanide were absent in whole mushroom. In fact, $P$. ostreatus was hydrolysed with commercially available proteinase $\mathrm{K}$, pepsin and trypsin with different concentrations of the enzymes $(0.05 \%, 0.10 \%$ and $0.15 \%)$, at different temperatures $\left(30{ }^{\circ} \mathrm{C}, 40^{\circ} \mathrm{C}\right.$ and $50^{\circ} \mathrm{C}$ ) for different time periods $(60,90$ and $120 \mathrm{~min}$ ) to get the mushroom protein hydrolysates. Degree of hydrolysis and protein content varied from $4.29 \pm 1.12 \%$ to $99.42 \pm 0.02 \%$ and from $0.25 \pm 0.07 \mathrm{mg} / \mathrm{mL}$ to $3.22 \pm 0.12 \mathrm{mg} / \mathrm{mL}$, respectively. Maximum degree of hydrolysis and the highest protein content of protein hydrolysate was obtained when using $0.15 \%$ proteinase $\mathrm{K}$, at $50^{\circ} \mathrm{C}$ for 120 minutes. Mushroom protein hydrolysates thus obtained exhibited improved functional characteristics such as foaming capacity, foaming stability and emulsifying property than the unhydrolysed mushroom. Based on the result of the present study, the mushroom protein hydrolysates could be served as useful ingredient for food and nutraceutical applications.
\end{abstract}

Keywords: Antinutrient; Mushroom protein hydrolysate; Degree of hydrolysis; RSM; Functional properties. 


\section{Resumo}

Pleurotus ostreatus, segundo cogumelo comestível mais cultivado, foi cultivado em palha de arroz, que é um resíduo barato e amplamente disponível. Após a colheita e secagem, a composição nutricional e antinutricional de $P$. ostreatus foi estimada utilizando os métodos de ensaio padrão. Tanino e ácido fítico foram encontrados em quantidade muito insignificantes $(0,095 \pm 0,027 \mathrm{mg} / \mathrm{gm}$ e $0,150 \pm 0,083 \mathrm{mg} / \mathrm{g}$, respectivamente), enquanto oxalato e cianeto estavam ausentes no cogumelo inteiro. $P$. ostreatus foi hidrolisado com proteinase $\mathrm{K}$ comercialmente disponível, pepsina e tripsina, com diferentes concentrações das enzimas (0,05\%, 0,10\% e 0,15\%), em diferentes temperaturas $\left(30^{\circ} \mathrm{C}, 40^{\circ} \mathrm{C}\right.$ e $50{ }^{\circ} \mathrm{C}$ ), para diferentes períodos de tempo (60, 90 e $120 \mathrm{~min}$ ), a fim de se obter os hidrolisados da proteína do cogumelo. O grau de hidrólise e o teor de proteínas variaram de 4,29 $\pm 1,12 \%$ a 99,42 $\pm 0,02 \%$ e 0,25 $\pm 0,07 \mathrm{mg} / \mathrm{mL}$ a 3,22 $\pm 0,12 \mathrm{mg} / \mathrm{mL}$, respectivamente. O grau máximo de hidrólise e o maior teor proteico foram obtidos ao utilizar $0,15 \%$ de proteinase $\mathrm{K}$, a $50{ }^{\circ} \mathrm{C}$ por 120 minutos. Os hidrolisados da proteína de cogumelo, assim obtidos, apresentaram características funcionais melhoradas em comparação ao cogumelo não hidrolisado, como capacidade de espuma, estabilidade de espuma e propriedade emulsificante,. Com base no resultado do presente estudo, essa proteína de cogumelo hidrolisada pode ser utilizada como ingrediente para aplicações alimentares e nutracêuticas.

Palavras-chave: Antinutrientes; Hidrolisado de proteína de cogumelos; Grau de hidrólise; RSM; Propriedades funcionais.

\section{Introduction}

Pleurotus ostreatus (Jacq.) P. Kumm., the most widely cultivated oyster mushroom, has some medicinal properties due to presence of bioactive compounds. In fact, $P$. mushroom contains various high molecular weight and low molecular weight bioactive compounds such as polysaccharides including $\beta$-glucans, terpenes, polypheols, fatty acid esters etc. (Golak-Siwulska et al., 2018); ferulic acid, coumaric acid (Gąsecka et al., 2016), pleuran etc. (Park et al., 2016). Its cultivation is lucrative because it can be easily grown on very cheaply and abundantly available lignocellulosic waste substrates. Mushrooms containing phytates, oxalate, tannins, etc. decrease the bioavailability of nutrients (Kadiri, 1990; Woldegiorgis et al., 2015). To quantify the safe limit of consumption of $P$. ostreatus, its antinutritional factors needs to be investigated.

In a study by Yuan et al., bioactive protein from P. eryngii (PEP) was isolated and amino acid sequence was analysed, where the authors found 17 novel unique peptides in it exhibiting anti-inflammatory properties (Yuan et al., 2017). Eighteen essential and non-essential amino acids were identified in Hericium erinaceus (Bull.) Pers. mushroom and the total amino acid content was $2.59 \pm 0.072(\% \mathrm{w} / \mathrm{w})$ (Sangtitanu et al., 2020).

In addition, mushroom protein has better digestibility ranged from $60 \%$ to $70 \%$ (Lavelli et al., 2018) and excellent amino acid profile as well as presence of phenolic compounds with various therapeutic properties like antidiabetic, anticarcinogenic, hepatoprotective, immunomodulatory, hypocholesteremia etc. (Chaturvedi et al., 2018). Protein hydrolysates have been identified as a mixture of low molecular weight peptides with as little as possible free amino acids produced from different sources of protein during their partial hydrolysis (McCarthy et al., 2013; Schaafsma, 2009). Hydrolysates can be produced both chemically and enzymatically. Enzymatic hydrolysis is more desirable for its better-quality product formation and ecofriendly nature, whereas chemical hydrolysis reduces protein quality and its bioactive value. In recent years, protein hydrolysates are extensively used not only as dietary supplements but also as a flavor enhancer in coffee whiteners, fortifying agents in soft drinks and juices. These can be also used as food additives, texture enhancers and pharmaceutical products (Liu \& Chiang, 2008; Zheng et al., 2006). Hydrolysis parameters (time, temperature, enzyme concentration) influence proteolysis resulting in Degree of Hydrolysis (DH). The DH is the principal parameter to be used in the hydrolysis optimization to obtain desired protein hydrolysates (Sujith \& Hymavathi, 2011). Goswami and Bhowal, reported about enzymatic hydrolysis of P. ostreatus 
through 2,4,6-trinitrobenzene sulfonic acid (TNBS) but optimization through Response Surface Methodology (RSM) was not performed to establish the DH\%. In addition, evaluation of functional properties of protein hydrolysates were not reported to assess the quality of the Mushroom Protein Hydrolysate (MPH) (Goswami \& Bhowal, 2015). Protein hydrolysates with improved emulsion stability index, emulsion activity index, foam capacity, oil and Water Holding Capacity (WHC) along with their nutritional value are successfully been used in various food formulations (Chatterjee et al., 2015). Oil Holding Capacity $(\mathrm{OHC})$ of protein hydrolysates is an important attribute which not only influences the taste but also affects their application in food industry (as example bakery) where oil absorption is essential. It is already reported earlier that higher $\mathrm{OHC}$ tends to avoid phase separation and assist in improving palatability and taste retention of many food products (cake, mayonnaise, salad dressing etc.). The present research focused on the analysis of nutritional and antinutritional composition of freshly cultivated $P$. ostreatus. This study aimed at optimization process to obtain protein hydrolysate ascertaining their functional properties.

\section{Materials and methods}

\subsection{Spawn collection for the cultivation of edible oyster mushroom}

Spawn of edible oyster mushroom $P$. ostreatus was collected from Vivekananda Institute of Biotechnology, Nimpith, West Bengal, in India and then properly stored at $4{ }^{\circ} \mathrm{C}$ for analysis. Proteinase $\mathrm{K}$ (ex. Tritirachium album (Type A), 30U/mg, Novozyme product), pepsin (from porcine gastric mucosa 0.7 FIP-U/mg) and trypsin (from pancreas $2000 \mathrm{U} / \mathrm{G}$ ) used for enzymatic hydrolysis and Bovine Serum Albumin (BSA) used as standard in soluble protein analyze were purchased from Sigma-Aldrich Corp. (MO).

Disodium tetraboratedecahydrate, Sodium dodecylsulfate (SDS), O-Pthalaldehyde (OPA), Dithiothreitol (DTT), and L-serine were also purchased from Sigma-Aldrich. Tannic acid, sulfosalcilic acid and, sodium phytate and all other chemicals and reagents used were of analytical grade and were purchased from Merck, India.

\subsection{Cultivation of mushroom}

Cultivation of $P$. ostreatus was performed by the following steps, i.e., substrate preparation, spawning and also cropping and harvesting. Spawn grown on paddy was used as the inoculums.

\subsection{Proximate analysis of cultivated $P$. ostreatus}

Nutritional composition of dried edible oyster mushroom (moisture, protein, carbohydrate, fat and ash) was determined according to Association of Official Analytical Chemists method with slight modifications. Moisture content was determined in the hot air oven at $80{ }^{\circ} \mathrm{C}$ to $100{ }^{\circ} \mathrm{C}$ for 24 hours. For the determination of soluble protein content, the lyophilized mushroom powder was pretreated with $0.1 \mathrm{~N} \mathrm{NaOH}$ solution for 45 minutes and then centrifuged at $6000 \mathrm{X} g$ for 15 minutes. The supernatant obtained was evaluated according to Folin-Lowry method. Fat content was determined by the Soxhlet method. Ash content was quantified by keeping the sample in muffle furnace for 6 hours at the temperature of $600{ }^{\circ} \mathrm{C}$. Total carbohydrate content was determined by anthrone method. All the experiments were performed in triplicate and the results were the average of the three values. 


\subsection{Determination of antinutritional properties}

\subsubsection{Oxalate}

The oxalate content of the cultivated P.ostreatus was determined according to the method described by Day and Underwood, 1986 method. Oxalate $(\mathrm{mg} / \mathrm{g}$ ) was calculated from the titer value using the following Equation 1:

Oxalate $\mathrm{mg} / \mathrm{g}=$ Titer Value $\times 0.9004$

\subsubsection{Tannin}

The cultivated powdered mushroom $(0.2 \mathrm{~g})$ was weighed, mixed with $10 \mathrm{~mL} 70 \%$ acetone in a screw cap test tube and was placed in an ice bath for 10 minutes for complete extraction of tannin. The extract was filtered and $0.2 \mathrm{~mL}$ of the supernatant was transferred to another test tube and diluted to $1 \mathrm{~mL}$ with distilled water, in which a $20 \% \mathrm{Na}_{2} \mathrm{CO}_{3}(2.5 \mathrm{~mL})$ and $0.3 \mathrm{~mL}$ of Folin reagent diluted with distilled water $(1: 2 \mathrm{v} / \mathrm{v})$ were added. The resulting solution was thoroughly mixed and after $45 \mathrm{~min}$ of incubation at room temperature, the absorbance of the developing blue color solution and the standard solution was measured at $700 \mathrm{~nm}$ using spectrophotometer (JASCO V-630). Tannic acid was used as standard.

\subsubsection{Phytic acid}

Phytate content in the cultivated P. ostreatus was determined using the previous methods (Latta \& Eskin, 1980; Vaintraub \& Lapteva, 1988).

\subsubsection{Cyanide}

This experiment was determined according to the method of Association of Official Analytical Chemists (1980).

\subsection{Preparation of mushroom protein hydrolysate}

Fresh and cleaned fruiting bodies of mushrooms were cut into small pieces, freeze dried and grinded. The powdered mushroom was homogenized (REMI Motors RQ-124 A) with distilled water at a ratio of 1:2 ratio $(\mathrm{w} / \mathrm{v})$ in room temperature. The concentration of substrate was $0.5 \%(\mathrm{w} / \mathrm{w})$ while preparing the mushroom protein hydrolysate. The powdered mushroom was centrifuged (REMI R-24) at $5000 \mathrm{rpm}$ for 10 minutes to remove the unwanted debris. To obtain protein hydrolysates, the supernatant obtained from the previous step, was hydrolysed separately using proteinase $\mathrm{k}$, pepsin and trypsin. The enzyme substrate ratio was $0.5 \%(\mathrm{w} / \mathrm{v})$, $0.10 \%(\mathrm{w} / \mathrm{v})$ and $0.15 \%(\mathrm{w} / \mathrm{v})$, respectively. Different proteolytic enzymes were used at the same activity levels to compare their hydrolytic efficiency. Hydrolysis was carried out at the respective optimum $\mathrm{pH}$ of each protease ( $\mathrm{pH} 8,1.5$ and 8 for proteinase $\mathrm{k}$, pepsin and trypsin, respectively). The $\mathrm{pH}$ of the solution was maintained at the desired value using $1 \mathrm{M} \mathrm{HCl}$ or $0.1 \mathrm{M} \mathrm{NaOH}$ during hydrolysis. Here, the same activity level denotes that, three different proteolytic enzymes were used in three different concentrations separately at their optimum $\mathrm{pH}$ range to get maximum hydrolytic capacity and compare the same among each other at that concentrations. The $\mathrm{pH}$ range was maintained at the respective optimum $\mathrm{pH}$ of the three enzymes to get better hydrolysis at that concentration. After incubation, sample aliquots were withdrawn from each of proteolytic mixtures and were immediately put in a boiling water bath for $10 \mathrm{~min}$ to inactivate different proteases. The protein hydrolysates thus obtained were cooled to room temperature, centrifuged at $8000 \mathrm{rpm}$ for 20 minutes to separate soluble and insoluble fractions. Finally, the soluble fraction was freeze-dried and 
Optimization of enzymatic hydrolysis of Pleurotus ostreatus derived proteins through RSM and evaluation of nutritional and functional qualities of mushroom protein hydrolysates

Goswami, B. et al.

stored at $-18^{\circ} \mathrm{C}$ for further analysis. Mushroom protein hydrolysates from oyster mushroom were labeled as Mushroom Protein Hydrolysate (MPH). The pH of final MPH was 7.

\subsection{Optimization of parameters affecting enzymatic hydrolysis by central composite design of response surface methodology}

Different process parameters such enzyme loading $(30 \mathrm{U} / \mathrm{g}$ for proteinase $\mathrm{k}, 0.7 \mathrm{U} / \mathrm{g}$ for pepsin and $2 \mathrm{U} / \mathrm{g}$ for trypsin), incubation temperature $\left(30^{\circ} \mathrm{C}\right.$ to $50{ }^{\circ} \mathrm{C}$ ), and reaction time (60 minutes to 120 minutes) during enzymatic hydrolysis by proteinase $\mathrm{K}$ were optimized by response surface methodology. The four levels +1 , $0,-1$ corresponded to lower, medium and higher value respectively (Table 1).

Table 1. Coded values of the independent variables of MPH.

\begin{tabular}{cccccccc}
\hline Factors & Parameters & Units & Types & Low actual & $\begin{array}{c}\text { High } \\
\text { actual }\end{array}$ & $\begin{array}{c}\text { Low coded } \\
(-\boldsymbol{\alpha})\end{array}$ & $\begin{array}{c}\text { High coded } \\
(+\boldsymbol{\alpha})\end{array}$ \\
\hline $\mathrm{A}$ & $\begin{array}{c}\text { Enzyme } \\
\text { loading }\end{array}$ & $\%$ & Numeric & 0.05 & 0.15 & -1 & +1 \\
\hline $\mathrm{B}$ & Temperature & ${ }^{\circ} \mathrm{C}$ & Numeric & 30 & 50 & -1 & +1 \\
\hline $\mathrm{C}$ & Time & minutes & Numeric & 60 & 120 & -1 & +1 \\
\hline
\end{tabular}

\subsection{Degree of hydrolysis (DH)}

DH is defined as the percent ratio of the number of peptide bonds broken to the total number of peptide bonds available for proteolytic hydrolysis. The DH of MPH using three proteases was determined spectrophotometrically by orthopthalaldehyde (OPA) method as described by Nielsen et al. (2001). The DH was determined from the following Formula 2 and $\mathrm{h}$ tot was dependent on the amino acid composition of the substrate.

$D H=h / h_{t o t} \times 100 \%$

$\mathrm{h}=$ number of hydrolyzed bonds; $\mathrm{h}$ tot $=$ total number of peptide bonds per protein equivalent

when the raw material has not been identified and $\alpha, \beta$ value was $1.00 \& 0.40$ and the $\mathrm{h}_{\text {tot }}$ was 8.6 likewise (Nielsen et al., 2001).

Determination of h (Equation 3):

Serine $-\mathrm{NH}_{2}=O D_{\text {sample }}-O D_{\text {dark }} / O D_{\text {standard }}-O D_{\text {dark }} * 0.9516 m e q v / L^{*} 0.1 * 100 X * P$

where serine- $\mathrm{NH}_{2}=$ meqv serine $\mathrm{NH}_{2} / \mathrm{g}$ protein; $\mathrm{X}=\mathrm{g}$ sample; $p=$ protein $\%$ in sample; 0.1 was the sample volume in liter $(\mathrm{L})$. $\mathrm{h}$ was then: $\mathrm{h}=\left(\right.$ serine- $\left.\mathrm{NH}_{2}-\beta\right) / \alpha$ meqv $/ \mathrm{g}$ protein, where $\alpha, \beta$ value was $1.00 \& 0.40$ and the $\mathrm{h}_{\text {tot }}$ was 8.6 (Adler-Nissen, 1986).

\subsection{Soluble protein content}

The protein content in the MPHs with different DH values was determined by Folin-Lowry method (Lowry et al., 1951) using BSA as the standard. 


\subsection{Determination of functional properties}

\subsubsection{Determination of emulsifying properties}

A mixture of $2 \mathrm{~mL}$ sunflower oil and $6 \mathrm{~mL} \mathrm{1 \% (w/v)} \mathrm{MPHs} \mathrm{were} \mathrm{mixed} \mathrm{at} \mathrm{pH}$ 7. The mixture was thoroughly homogenized for $10 \mathrm{~min}$ at room temperature. Aliquot of $50 \mu \mathrm{l}$ of emulsion was collected from the bottom of the tube immediately and after $10 \mathrm{~min}$ of emulsion formation and both the emulsions were diluted up to $5 \mathrm{~mL}$ with $1 \%$ (w/v) Sodium Dodecyl Sulphate (SDS). Absorbance of both the diluted aliquots designated as $\mathrm{A}_{0}$ (immediately sampled) and $\mathrm{A}_{10}$ (sample after 10 min of emulsion formation) were measured spectrophotometrically at $500 \mathrm{~nm}$. Emulsifying Activity Index (EAI) and Emulsion Stability Index (ESI) were calculated as follows (Equations 4 and 5):

$$
E A I\left(m^{2} / g\right)=2 \times 2.303 \times A_{500 \mathrm{~nm}} \times \text { protein weight }(\mathrm{gm}) / F
$$

where, $\mathrm{F}=$ oil volume fraction.

$$
\operatorname{ESI}(\min )=A_{0} \times t / A
$$

where, $\mathrm{t}=10$ minutes, $\mathrm{A}=\mathrm{A}_{0}-\mathrm{A}_{10}$.

\subsubsection{Determination of foaming properties}

Foaming properties including Foaming Capacity (FC) and Foaming Stability (FS) of unhydrolysed and proteinase $\mathrm{K}$ treated protein hydrolysates obtained from $P$. ostreatus cultivated on paddy straw were determined according to Jamdar et al. (2010). The following Equations 6 and 7 were used for calculating the FC and FS:

$$
\begin{aligned}
& F C(\%)=\left(V_{t}-V_{0}\right) \times 100 \times V_{0} \\
& F S(\%)=\left(V_{t}-V_{0}\right) \times 100 / V_{0}
\end{aligned}
$$

\subsubsection{Water holding capacity (WHC)}

$1 \mathrm{~g}$ dried oyster mushroom was taken in a centrifuge tube and mixed with $10 \mathrm{~mL}$ of distilled water and weighed properly. Then the slurry was stirred for $1 \mathrm{hr}$ at room temperature and kept aside for 30 minutes without disturbances. It was centrifuged at $5000 \mathrm{rpm}$ for $10 \mathrm{~min}$, supernatant was discarded and the tube was again weighed (Equation 8).

$$
\text { Percentage of } W H C=\left(W_{1}-W_{2}\right) / W_{0} \times 100 \%
$$

$\mathrm{W}_{0}=$ Weight of the sample; $\mathrm{W}_{1}=$ Previously weighed sample dispersed in distilled water + tube; $\mathrm{W}_{2}=$ Final weight of sample after centrifugation + tube.

\subsubsection{Oil holding capacity (OHC)}

$0.5 \mathrm{~g}$ of powdered MPHs was mixed with sunflower oil in a centrifuge tube and stirred for 30 minutes at room temperature. It was allowed to stand for 30 minutes. The mixture was centrifuged at $5000 \mathrm{rpm}$ for 10 minutes, the oil was discarded and final weight of the tube was taken (Equation 9).

Percentage of $\mathrm{OHC}=\left(W_{1}-W_{2}\right) / W_{0} \times 100 \%$ 
$\mathrm{W}_{0}=$ Weight of the sample; $\mathrm{W}_{1}=$ Previously weighed sample dispersed in oil + tube; $\mathrm{W}_{2}=$ Final weight of sample after centrifugation + tube.

\subsection{Statistical analysis}

All experiments were done in triplicate and standard deviation was determined. To determine the significance, the data was analysed by One-way Analysis of Variance (ANOVA) using post-hoc Tukey's Honest Significant Difference (HSD) Test. Tukey's test was performed for $p$-value determination. Values of $p \leq 0.05$ and $p \leq 0.01$ were considered as significant value.

\section{Results and discussion}

\subsection{Cultivation of $P$. ostreatus}

The productivity of edible mushrooms is dependent on genetic and biochemical factors like the species, the type of spawn, the substrates, moisture content, physiochemical conditions, etc. (Kirbag \& Akyuz, 2008; Onuoha et al., 2009). P. ostreatus mushroom, commercially known as oyster mushroom (Sánchez, 2010), can be cultivated on a wide range of lignocellulosic waste substrates (Josiane et al., 2018; Ogundele et al., 2017; Oyetayo \& Ariyo, 2013). It was reported earlier that in cultivation of $P$. ostreatus, a high percentage of the substrate could be converted to fruiting bodies and their fruiting bodies were not affected by pests and disease (Sánchez, 2009). Based on these observations it may be concluded that $P$. ostreatus can be cultivated in a simple and financially efficient manner and thus, it became an excellent choice for mushroom production. In the current study, $P$. ostreatus was successfully and economically grown on paddy straw. Paddy straw has been preferred as the substrate for its financial efficiency and abundance. The nutritional composition, as obtained through proximate analysis, of the mushroom in the current study is compatible with what has been reported by other previous studies who used costlier substrates like pineapple rind (Narh et al., 2018), banana leaves, groundnut shell, cassava and yam peel and sawdust, etc. (Peter et al., 2019) (discussed in details in Section 3.2). Moreover, the growth time for the fruiting bodies has been found to be shorter in the current study (20 days) in comparison to other studies (34 days for pineapple rind (Narh et al., 2018)) though the productivity could have been still maintained.

\subsection{Proximate analysis of cultivated $P$. ostreatus}

The proximate composition of dried oyster mushroom P.ostreatus cultivated on paddy straw was shown in Table 2. Moisture content of dried P. ostreatus in our study was $8.43 \pm 0.05 \%$ which was in the range of the report of Oyetayo and Ariyo (9-13\%) (Miles \& Chang, 2004; Oyetayo \& Ariyo, 2013). Ogundele et al. found that moisture content of $P$. ostreatus harvested from hardwood sawdust was higher $(8.93 \%)$ than that harvested from softwood sawdust (7.88\%) (Ogundele et al., 2017). The moisture content of P. ostreatus evaluated by Tolera and Abera was $8.45 \pm 1.65 \%$, which was similar with the experimental finding but on the other hand, Narh et al., reported higher moisture content of $P$. ostreatus ranged from $10.56 \pm 0.12 \mathrm{~g} / 100 \mathrm{~g}$ $\mathrm{dw}$ to $10.69 \pm 0.02 \mathrm{~g} / 100 \mathrm{~g}$ dw cultivated on composted sawdust supplemented with powdered pineapple ring (Narh et al., 2018; Tolera \& Abera, 2017). Narh et al. (2018) reported that entire fruiting bodies were sundried, milled and refrigerated at $-10{ }^{\circ} \mathrm{C}$. The mushrooms were harvested on a varying concentration of powdered pineapple rind $(2 \%, 5 \%$ and $12 \%)$. The moisture content varied from $10.56 \pm 0.12 \%$ to $10.84 \pm 0.04 \%$. This might be due to different capacity of moisture absorption of the mushrooms from the environment. In sun drying, case hardening might happen and cause the outer surface dry and hard while prevents moisture escaping from the inner surface.

In our study, protein content of dried mushroom was $26.8 \pm 0.40 \%$. This result was in the same line as Tolera and Abera, (2017) and Ogundele et al., (2017) who cultivated the same strain of P. ostreatus on 
cottonseed waste and hardwood sawdust respectively. Protein percentage of dried oyster mushroom evaluated by Narh et al. (2018) was relatively lower $(20.41 \pm 0.01-0.04 \mathrm{~g} / 100 \mathrm{~g} \mathrm{dw})$ than the experimental result. Our results showed higher protein content than the study conducted by Hoa et al. where P. ostreatus grown on $100 \%$ sawdust (SD) or $50 \%$ sawdust and $50 \%$ sugarcane bagasse (SB) or $80 \%$ SD \& $20 \%$ SB waste or $50 \% \mathrm{SD} \& 50 \%$ corncob (CC) or $80 \% \mathrm{SD} \& 20 \% \mathrm{CC}$ as substrate exhibited the protein content of $19.52 \%$, $24.17 \%, 21.88 \%, 25.65 \%$ and $20.89 \%$, respectively (Hoa et al., 2015). These findings clearly demonstrated that protein content of the mushroom which constituted of more than half of total nitrogen depended on the substrate. In addition, paddy straw mushroom contains higher percentage of essential amino acids (Ahlawat \& Tewari, 2007), when compared to other plant biomass, such as softwood, paddy straw contains higher amount of hemicelluloses content and low in lignin and cellulose contents respectively (Barmina et al., 2013). The authors cultivated the mushroom on various lignocellulosic substrates like pineapple rind, sawdust, bagasse which is full of vitamins and microelements, but we cultivated mushroom only on paddy straw. The results interpreted that our mushroom was nutritionally superior to others.

Carbohydrate is the major source of energy in our body. In our study, carbohydrate content of dried P. ostreatus was $50.77 \pm 1.36 \%$. On the other hand, Tolera \& Abera (2017) showed that carbohydrate content of $P$. ostreatus was $42.14 \%$. Studies carried out by Ogundele et al. (2017) showed that on a dry basis, carbohydrate content of $P$. ostreatus from hardwood sawdust was lower (41.57\%) when compared to that harvested from softwood sawdust (52.04\%). According to Narh et al. (2018), $59.08 \pm 0.02 \mathrm{gm} / 100 \mathrm{~g} \mathrm{dw}$ of carbohydrate was present in $P$. ostreatus grown on sawdust compost supplemented with $5 \%$ powdered pineapple rind as an organic substance which was higher than the experimental findings. As carbohydrate was found to be in considerable amount in our cultivated $P$. ostreatus, this can be attributed that it may assist in sustaining proper functioning of brain, heart, digestive system and boost immunity.

Ash content of the oyster mushroom on dry basis in this study was $5.5 \pm 0.12 \% \mathrm{~g} / 100 \mathrm{~g}$ which was only $3 \%$ lower than the report noted by Narh et al. (2018) $(8.40 \pm 0.09 \mathrm{gm} / 100 \mathrm{gm}$ for $P$. ostreatus grown on sawdust compost supplemented with 5\% powdered pineapple rind as an organic substance) whereas $5.90 \%$ of ash content was found in the P. ostreatus grown on $100 \%$ sawdust used as substrate which was almost similar to our findings (Hoa et al., 2015). Ash content denotes that $P$. ostreatus is full of minerals which are necessary for body building.

Fat content of our cultivated dried oyster mushroom was $2.98 \pm 0.11 \%$. Similar results were also reported by Tolera \& Abera (2017). On the other hand, P. ostreatus cultivated on rice bran supplemented media exhibited 1\% lower fat content (Narh et al., 2018). Our mushroom contains low fat, high carbohydrate and protein, so this can be successfully included as a low-calorie high protein rich food.

In this study the result of dietary fiber from the dried sample was $8.43 \pm 0.05 \%$ which was significantly lower (12.87\%) than reported by Tolera \& Abera (2017). Comparatively, Ogundele et al. (2017) showed that crude fiber content of $P$. ostreatus harvested from hardwood sawdust was $9.59 \%$.

The proximate composition of $P$. ostreatus grown and harvested from different substrates was variable due to difference nutritional composition of various substrates. Our findings clearly indicated that paddy straw exhibited good potential as substrate for cultivation of oyster mushroom resulting in good proximate content. High protein content of $P$. ostreatus implied that this mushroom can be included in diet to aid protein supply especially to low-income group and assist in lessening malnutrition problem.

\subsection{Antinutritional properties}

Some of the antinutrients studied in this research paper were oxalate, tannin, phytate and cyanide (Table 2).

\subsubsection{Oxalate}

Oxalate hampers the mineral absorption in the human body by binding with calcium, magnesium and iron (Ogundele et al., 2017). In our research study, oxalate was absent in the edible oyster mushroom P. ostreatus 
cultivated on paddy straw. A previous study demonstrated that, oxalate content of $P$. ostreatus (Jacq.) of Akwa Ibom state of five different locations of Nigeria ranged from $166.9 \pm 6.50 \mathrm{mg} / \mathrm{g}$ to $301.9 \pm 4.90 \mathrm{mg} / \mathrm{g}$ (Godwin, 2015). The oxalate content, as reported in this study, was higher with respect to similar findings in the existing literature which might be due to the effect of climatic condition in Akwa Ibom and due to the effect of growing substrates. Since $P$. ostreatus, cultivated in this study, did not contain oxalate, it can be regarded as safe for consumption.

\subsubsection{Tannin}

This present study revealed that tannin content of the P. ostreatus was $0.095 \pm 0.027 \mathrm{mg} / \mathrm{g}$, which was within the standard safe limit $(60.00 \mathrm{mg} / 100 \mathrm{~g})$. Tannin content of the mushroom species evaluated by Adeduntan were of significantly low ranging from $0.035 \mathrm{mg} / \mathrm{g}$ to $0.116 \mathrm{mg} / \mathrm{g}$ (Adeduntan, 2014). According to this study, P. sajorcaju contained $0.080 \mathrm{mg} / \mathrm{gm}$ of tannin which was almost similar to the experimental result. According to Gaur et al., 2016 tannin content of six different edible mushroom species ranged between 0.41-0.57 mg/g which was higher than reported in the present investigation. Our study could reveal that tannin content was significantly lower than the above stated results, almost in trace quantities. It was reported that high level of tannin intake formed insoluble complexes with protein and affected the bioavailability of protein (Aletor, 1995), digestibility and palatability (Akwaowo et al., 2000; Okwu \& Ndu, 2006). But recent studies demonstrated that only small quantities of tannin may be beneficial (Godwin, 2015). Tannin content is generally lower in cap and tuber than stalk. Since it is within the limit (10\% on dry weight basis), it will not affect the body (Osagie et al., 1998).

\subsubsection{Phytic acid}

Phytates are inositol hexaphosphoric acids which can bind with calcium, zinc, magnesium, iron, hence inhibit the nutrient absorption in the body (Oly-Alawuba \& Obiakor-Okeke, 2014). Our result showed that edible oyster mushroom P. ostreatus contained very negligible amount of phytic acid i.e. $0.15 \pm 0.083 \mathrm{mg} / \mathrm{g}$, which was far lesser than the safe limit of $22.10 \mathrm{mg} / 100 \mathrm{~g}$ (Oly-Alawuba \& Obiakor-Okeke, 2014). According to Gaur et al., Agaricus bisporus contained $0.11 \pm 0.01 \mathrm{mg} / \mathrm{g}$ phytic acid and both Calocybe indica and Macrocybe gigantea (Massee) contained $0.19 \pm 0.01 \mathrm{mg} / \mathrm{g}$ of phytic acid (Gaur et al., 2016). Woldegiorgis et al. (2015) also showed that $P$. ostreatus of Ethiopia contained $155.8 \pm 12.1 \mathrm{mg} / 100 \mathrm{~g}$ of phytic acid (Woldegiorgis et al., 2015). Presence of $1 \%$ or more phytate content in our diet could affect mineral bioavailability. Phytate content of P. ostreatus considered in this study can be regarded as edible.

\subsubsection{Cyanide}

As cyanide is a potential inhibitor of the respiratory chain, it is found to be very toxic at low concentration to animal (Oly-Alawuba \& Obiakor-Okeke, 2014). Our results showed that, no cyanide was present in the dried P. ostreatus mushroom. In the study conducted by Oly-Alawuba \& Obiakor-Okeke (2014) cyanide content in three different mushrooms varied from $0.198 \pm 0.06$ to $0.236 \pm 0.04 \mathrm{mg} / \mathrm{gm}$. Ijioma Blessing et al. (2015) reported that, HCN content in three edible mushrooms (Temitomyces sp., Russula sp. and P. tuberregium) of South eastern Nigeria were ranged from $0.0019-0.13 \mathrm{mg} / 100 \mathrm{gm}$.

Table 2. Nutrient and antinutrient compositon of dried P.ostreatus cultivated on paddy straw.

\begin{tabular}{cccc}
\hline & Nutrients (\%) & \multicolumn{2}{c}{ Antinutrients (mg/g) } \\
\hline Moisture & $5.52 \pm 0.34$ & Oxalate & ND \\
\hline Protein & $26.8 \pm 0.40$ & & Tannin \\
\hline Carbohydrate & $50.77 \pm 1.36$ & & $0.095 \pm 0.027$ \\
\hline Fat & $2.98 \pm 0.11$ & Phytate & $0.15 \pm 0.083$ \\
\hline Ash & $5.5 \pm 0.12$ & & Cyanide \\
\hline Dietary fibre & $8.43 \pm 0.05$ & & ND \\
\hline
\end{tabular}

$\mathrm{ND}=$ Not Detected. 


\subsection{Degree of hydrolysis}

Determination of DH is essential to achieve desired enzymatic protein hydrolysates through optimization. Table 3 demonstrated the wide range of $\mathrm{DH}$ values obtained by the action of proteinase $\mathrm{K}$, pepsin and trypsin respectively using different operational conditions and it was observed that DH ranged from $7.8 \pm 2.06 \%$ $99.42 \pm 0.02 \%$. Among the three proteolytic enzymes, highest \% DH of MPH was achieved by proteinase K followed by pepsin and trypsin. The highest $\% \mathrm{DH}$ of MPHs observation indicated the maximum cleavage of mushroom proteins into peptides and free amino acids.

\subsection{Optimization of various process parameters of degree of hydrolysis through response surface methodology}

The Response Surface Methodology (RSM) is a widely used mathematical and statistical tool for modeling and analyzing a process in which the response of interest is affected by various variables and the objective of this method is to develop, improve and optimize the response. RSM evaluates an appropriate approximation relationship between input and output variables and identify the optimal operating conditions for a system under study or a region of the factor field that satisfies the operating requirements.

Different independent variables were studied for its effect upon degree of hydrolysis (DH) (\%) of proteinase $\mathrm{k}$, pepsin and trypsin treated MPH respectively. There were total of 10 runs were carried out for optimization of the different parameters by central composite design methodology. The quadratic polynomial diagnostic model was chosen for the elucidation of significant model based on the ANOVA statistical analysis. The following equation was derived for the analysis of the DH (\%) of proteinase $\mathrm{k}$, pepsin and trypsin treated MPH.

The Equation 10 for proteinase $\mathrm{k}$ treated MPH

$Y_{1}=4.22061+89.27331 A+0.98886 B+0.14169 C$

The Equation 11 for pepsin treated MPH

$Y_{2}=68.49+12.37 A+8.22 B+1.81 C$

The Equation 12 for trypsin treated MPH

$Y_{3}=25.68+5.26 A+23.428 B+3.50 C$

where, $\mathrm{Y}_{1}=\mathrm{DH}(\%)$ of proteinase $\mathrm{k}$ treated $\mathrm{MPH}, \mathrm{Y}_{2}=\mathrm{DH}(\%)$ pepsin treated $\mathrm{MPH}, \mathrm{Y}_{3}=\mathrm{DH}(\%)$ of trypsin treated $\mathrm{MPH}, \mathrm{A}=$ Enzyme loading $(\%), \mathrm{B}=$ Temperature $\left({ }^{\circ} \mathrm{C}\right), \mathrm{C}=$ time (minutes)

The coefficient of adjusted A response surface model was chosen for the validation of experimental design set up obtained by varying parameters affecting the DH (\%) for different hydrolytic enzymes treated MPH. The lack of fit model has shown significance thereby the model is applicable for optimization parameters evaluation (Table 4).

The surface plots of two combining parameters were presented for the presentation of the optimized factors responsible for $\mathrm{DH} \%$. Substrate loading and enzyme loading has significant effect in enzymatic hydrolysis process. Substrate loading has achieved maximum hydrolysis efficiency for all of the three proteolytic enzymes depicted in Figures 1a, 1b, 2a, 2b and 3a, 3b. The 0.15\% enzyme concentration achieved better hydrolysis efficiency for both proteinase $\mathrm{k}$ and pepsin, whereas trypsin showed lower hydrolysis efficacy. Effect of temperature and time assists in increment of hydrolysis rate. The optimum parameters for proteinase $\mathrm{k}$ enzyme were found to be $112.82 \mathrm{~min}$ at the temperature of $50.51^{\circ} \mathrm{C}$ and the $\mathrm{DH} \%$ was $84.06 \%$; whereas the same amount of hydrolysis (i.e., $84.06 \%$ ) was achieved at $106.54 \mathrm{~min}$ at the temperature of $41.9^{\circ} \mathrm{C}$ in 
Optimization of enzymatic hydrolysis of Pleurotus ostreatus derived proteins through RSM and evaluation of nutritional and functional qualities of mushroom protein hydrolysates

Goswami, B. et al.

case of pepsin. Lastly, MPHs treated by trypsin was optimized at the concentration of $0.08 \%$ after 61.61 minutes of hydrolysis and at the temperature of $41.45^{\circ} \mathrm{C}$.

Table 3. Optimization of various process parameters of DH and protein content of proteinase $\mathrm{K}$, pepsin and trypsin treated MPHs (P. ostreatus).

\begin{tabular}{|c|c|c|c|c|c|c|}
\hline Run & $\begin{array}{c}\text { Enzyme loading } \\
(\% \mathrm{w} / \mathrm{v})\end{array}$ & $\begin{array}{c}\text { Temperature } \\
\left({ }^{\circ} \mathrm{C}\right)\end{array}$ & $\begin{array}{c}\text { Time } \\
\text { (minutes) }\end{array}$ & $\begin{array}{c}\text { Degree of } \\
\text { Hydrolysis (\%) } \\
\text { (proteinase k) }\end{array}$ & $\begin{array}{c}\text { Degree of } \\
\text { Hydrolysis (\%) } \\
\text { (pepsin) }\end{array}$ & $\begin{array}{c}\text { Degree of } \\
\text { Hydrolysis (\%) } \\
\text { (trypsin) }\end{array}$ \\
\hline 1 & 0.10 & 40.00 & 90.00 & 65.54 & 62.45 & 18.63 \\
\hline 2 & 0.15 & 50.00 & 120.00 & 99.42 & 85.02 & 65.35 \\
\hline 3 & 0.15 & 50.00 & 60.00 & 78.27 & 74.22 & 53.21 \\
\hline 4 & 0.05 & 30.00 & 120.00 & 65.23 & 77.19 & 7.80 \\
\hline 5 & 0.10 & 40.00 & 140.45 & 57.32 & 61.29 & 04.24 \\
\hline 6 & 0.10 & 40.00 & 90.00 & 65.54 & 62.45 & 18.63 \\
\hline 7 & 0.10 & 40.00 & 90.00 & 65.54 & 62.45 & 18.63 \\
\hline 8 & 0.15 & 30.00 & 60.00 & 58.29 & 55.63 & 12.42 \\
\hline 9 & 0.18 & 40.00 & 90.00 & 63.21 & 65.32 & 39.82 \\
\hline 10 & 0.05 & 50.00 & 60.00 & 60.94 & 74.22 & 53.21 \\
\hline
\end{tabular}

Table 4. Analysis of variance of the different independent variables of the response surface plots of DH (\%) of proteinase $\mathrm{k}$, pepsin and trypsin treated MPH.

\begin{tabular}{|c|c|c|c|c|c|c|}
\hline Proteolytic enzymes & Source & $\begin{array}{c}\text { Sum of } \\
\text { squares }\end{array}$ & $\begin{array}{l}\text { Degree of } \\
\text { freedom }\end{array}$ & $\begin{array}{l}\text { Mean } \\
\text { square }\end{array}$ & $F$-value & $P$-value \\
\hline \multirow{7}{*}{$\begin{array}{c}\text { Proteinase k treated } \\
\text { MPH }\end{array}$} & Model & 691.39 & 3 & 230.44 & 1.95 & 0.2227 \\
\hline & $\begin{array}{l}\text { Residual } \\
\text { error }\end{array}$ & 708.29 & 6 & 118.05 & & \\
\hline & Lack of fit & 708.29 & 4 & 177.07 & 4.66 & 0.0230 \\
\hline & Pure error & 0.000 & 2 & 0.000 & & \\
\hline & Total & 1399.60 & 9 & $\mathrm{R}^{2}$ & 0.4939 & \\
\hline & & & & Adjusted $\mathrm{R}^{2}$ & 0.2409 & \\
\hline & & & & Predicted $\mathrm{R}^{2}$ & 0.1150 & \\
\hline \multirow{7}{*}{ Pepsin treated MPH } & Model & 557.79 & 6 & 92.97 & 1.46 & 0.3507 \\
\hline & $\begin{array}{l}\text { Residual } \\
\text { error }\end{array}$ & 191.35 & 3 & 63.78 & & \\
\hline & Lack of fit & 191.35 & 1 & 191.35 & 1.66 & 0.00037 \\
\hline & Pure error & 0.000 & 2 & 0.000 & & \\
\hline & Total & 749.19 & 9 & $\mathrm{R}^{2}$ & 0.7446 & \\
\hline & & & & Adjusted $\mathrm{R}^{2}$ & 0.2337 & \\
\hline & & & & Predicted $\mathrm{R}^{2}$ & 0.1949 & \\
\hline \multirow{7}{*}{ Trypsin treated MPH } & Model & 3378.73 & 3 & 1126.24 & 7.58 & 0.0183 \\
\hline & $\begin{array}{l}\text { Residual } \\
\text { error }\end{array}$ & 891.54 & 6 & 148.59 & & \\
\hline & Lack of fit & 891.54 & 4 & 222.82 & 1.66 & 0.00037 \\
\hline & Pure error & 0.000 & 2 & 0.000 & & \\
\hline & Total & 4270.27 & 9 & $\mathrm{R}^{2}$ & 0.7912 & \\
\hline & & & & Adjusted $\mathrm{R}^{2}$ & 0.6868 & \\
\hline & & & & Predicted $\mathrm{R}^{2}$ & 0.1931 & \\
\hline
\end{tabular}



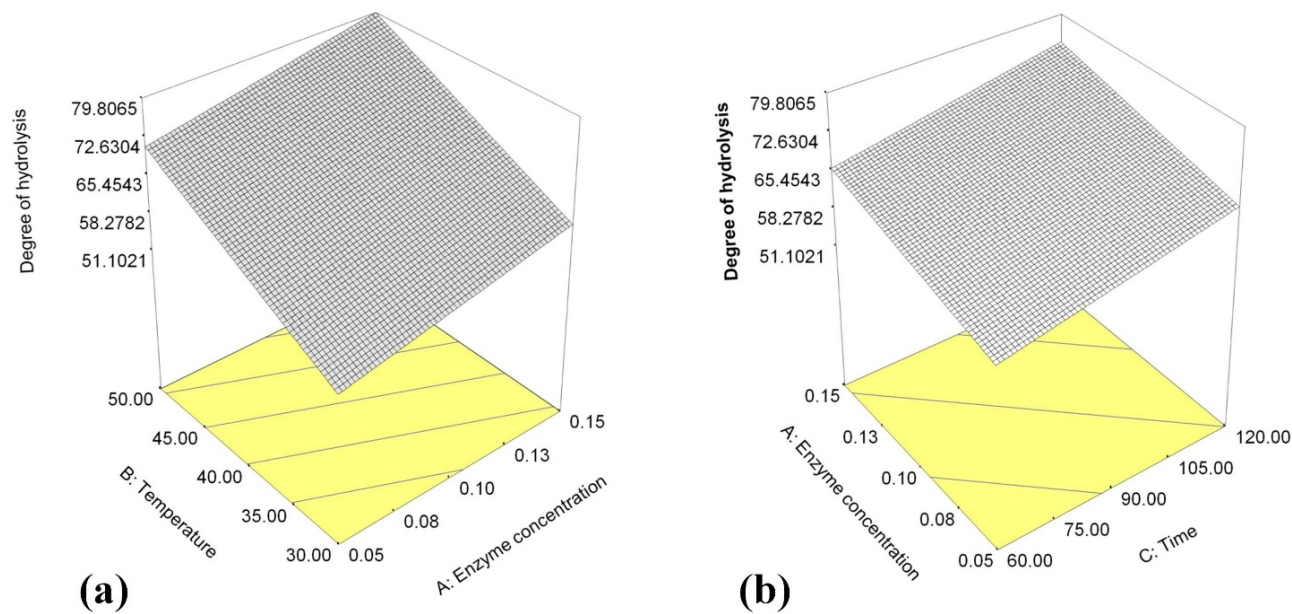

Figure 1. (a) Pictographic representation of optimization of various process parameters of DH and protein content of proteinase K treated MPHs (P. ostreatus) in respect of temperature; (b) Pictographic representation of optimization of various process parameters of $\mathrm{DH}$ and protein content of proteinase $\mathrm{K}$ treated MPHs (P. ostreatus) in respect of time.
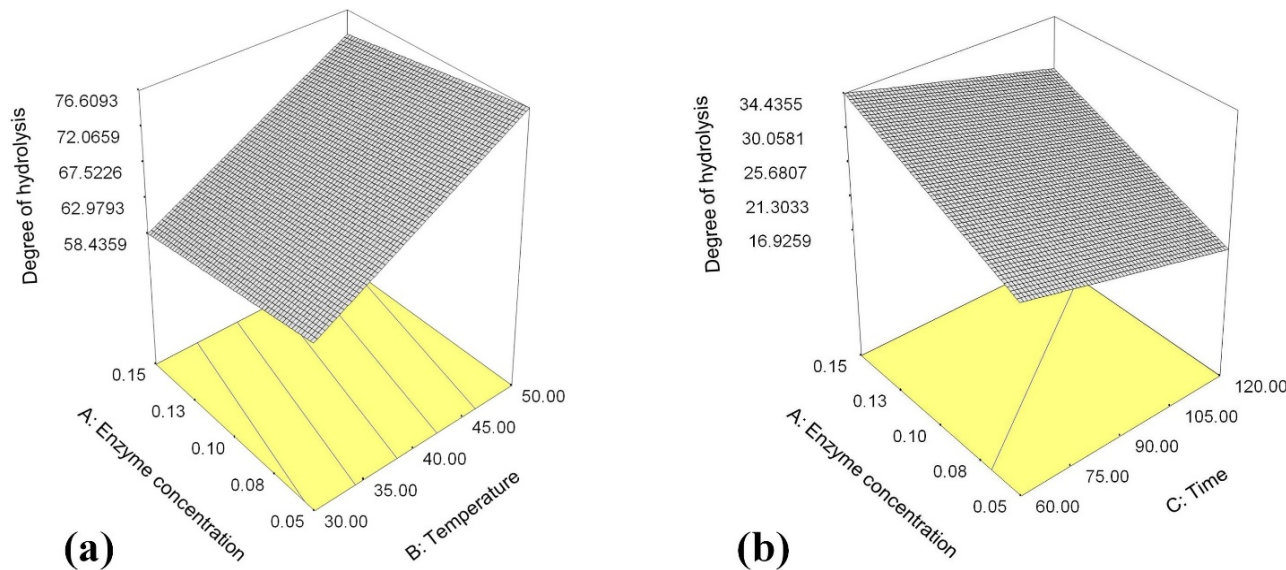

Figure 2. (a) Pictographic representation of optimization of various process parameters of DH and protein content of pepsin treated MPHs (P. ostreatus) in respect of temperature; (b) Pictographic representation of optimization of various process parameters of DH and protein content of pepsin treated MPHs (P. ostreatus) in respect of time
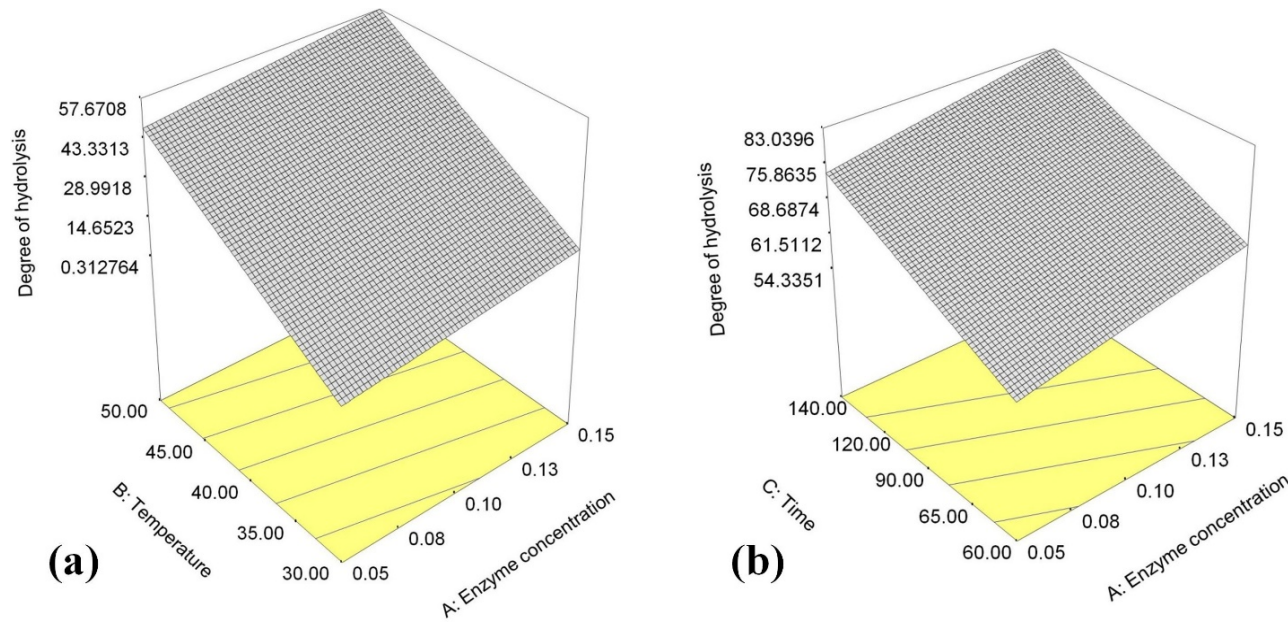

Figure 3. Pictographic representation of optimization of various process parameters of DH and protein content of trypsin treated MPHs (P. ostreatus) in respect of temperature; (b) Pictographic representation of optimization of various process parameters of $\mathrm{DH}$ and protein content of trypsin treated MPHs (P. ostreatus) in respect of time. 


\subsection{Protein content}

Table 5 represented the protein content in the hydrolysates obtained using different proteolytic enzymes exhibited that it gradually increased as the enzyme concentration, temperature as well as the time of hydrolysis increased. The maximum protein content $(3.22 \pm 0.12 \mathrm{mg} / \mathrm{mL})$ of MPH was obtained by proteinase $\mathrm{K}$ at $50{ }^{\circ} \mathrm{C}$ with the enzyme concentration of $0.15 \%$ after 120 minutes of hydrolysis followed by pepsin $(2.01 \pm 0.1 \mathrm{mg} / \mathrm{mL})$ and trypsin $(1.65 \pm 0.03 \mathrm{mg} / \mathrm{mL})$ under the same hydrolytic conditions. Thus, trypsin showed lowest protein content of $0.59 \pm 0.06 \% \mathrm{mg} / \mathrm{mL}$ with $0.05 \%$ enzyme concentrations at $30{ }^{\circ} \mathrm{C}$ for 30 minutes of hydrolysis. It has been observed in the current study that the soluble protein content of the MPH could increase with increase in certain parameters which were $\mathrm{DH} \%$, concentration of certain proteolytic enzymes and temperature. Mushroom protein holds high $\mathrm{pH}$ and thermal stability which point out for minimal denaturation of protein upon food processing (Erjavec et al., 2012). Proteinase $\mathrm{K}$ is a highly active and stable endopeptidase with broad spectrum of cleaving capacity of peptide bonds, mostly after carboxyl group of $\mathrm{N}$ terminal of aliphatic and aromatic amino acids, also cleaves the ester and amide bonds. So, in this current study, $0.15 \%$ proteinase $\mathrm{K}$ was able to hydrolyse almost whole mushroom protein cleaving peptide bonds and releasing amino acids in the reaction mixtures readily available for absorption in the body. Till date, this is the first study which establishes that MPH of $P$. ostreatus could be an excellent source of nutraceuticals cum easily digestible food ingredients which can be used in food formulation. In the study of (Greeshma \& Sridhar, 2018), the uncooked Amanita mushroom showed $32 \%$ protein solubility at $\mathrm{pH} 2$ and $27 \%$ as protein solubility decreased with increasing $\mathrm{pH}$ till the isoelectric point. This can be useful in food formulation like carbonated beverages and infant foods. Gonzalez et al. reported that protein solubility of mushroom flour varied from $0.035 \pm 0.005$ and $0.51 \pm 0.02 \mathrm{mg} / \mathrm{ml}$ (González et al., 2021). With the increment of $\mathrm{pH}$, the solubility of protein increased because the $\mathrm{pH}$ rage (3-12) near to the isoelectric point at which the electrostatic force was diminished. As a result, the protein tends to precipitate.

Table 5. Optimization of various process parameters of DH and protein content of proteinase K, pepsin and trypsin treated MPHs (P. ostreatus).

\begin{tabular}{|c|c|c|c|c|c|c|c|}
\hline \multirow{3}{*}{$\begin{array}{c}\text { Enzyme } \\
\text { concentration } \\
(\%)\end{array}$} & \multirow{3}{*}{$\begin{array}{c}\text { Temp } \\
\left({ }^{\circ} \mathrm{C}\right)\end{array}$} & \multicolumn{6}{|c|}{ Proteinase K } \\
\hline & & \multicolumn{2}{|c|}{$60 \mathrm{~min}$} & \multicolumn{2}{|c|}{$90 \mathrm{~min}$} & \multicolumn{2}{|c|}{$120 \mathrm{~min}$} \\
\hline & & $\begin{array}{c}\text { Degree of } \\
\text { hydrolysis (\%) } \\
\end{array}$ & $\begin{array}{l}\text { Protein content } \\
(\mathrm{mg} / \mathrm{ml})\end{array}$ & $\begin{array}{c}\text { Degree of } \\
\text { hydrolysis (\%) }\end{array}$ & $\begin{array}{l}\text { Protein content } \\
(\mathrm{mg} / \mathrm{ml})\end{array}$ & $\begin{array}{c}\text { Degree of } \\
\text { hydrolysis (\%) }\end{array}$ & $\begin{array}{c}\text { Protein content } \\
(\mathrm{mg} / \mathrm{ml})\end{array}$ \\
\hline \multirow{3}{*}{0.15} & 50 & $78.27 \pm 1.75^{\mathrm{a}, \mathrm{b}}$ & $2.32 \pm 0.01^{\mathrm{c}, \mathrm{d}}$ & $97.58 \pm 0.98^{\mathrm{a}, \mathrm{b}}$ & $3.16 \pm 0.03^{\mathrm{c}, \mathrm{d}}$ & $99.42 \pm 0.02$ & $3.22 \pm 0.12^{\mathrm{c}, \mathrm{d}}$ \\
\hline & 40 & $60.58 \pm 1.87^{\mathrm{a}, \mathrm{b}}$ & $2.11 \pm 0.02^{\mathrm{c}, \mathrm{d}}$ & $79.03 \pm 2.03^{\mathrm{a}, \mathrm{b}}$ & $2.5 \pm 0.02^{\mathrm{c}, \mathrm{d}}$ & $98.29 \pm 1.13$ & $3.16 \pm 0.07^{\mathrm{c}, \mathrm{d}}$ \\
\hline & 30 & $58.29 \pm 0.86^{\mathrm{a}, \mathrm{b}}$ & $2.05 \pm 0.08^{\mathrm{c}, \mathrm{d}}$ & $70.39 \pm 1.71^{\mathrm{a}, \mathrm{b}}$ & $2.19 \pm 0.03^{\mathrm{c}, \mathrm{d}}$ & $72.52 \pm 2.18$ & $2.11 \pm 0.016^{\mathrm{c}, \mathrm{d}}$ \\
\hline \multirow{3}{*}{0.10} & 50 & $70.48 \pm 1.79^{\mathrm{b}, \mathrm{c}}$ & $1.44 \pm 0.02^{\mathrm{c}, \mathrm{d}}$ & $95.24 \pm 2.07^{\mathrm{a}, \mathrm{b}}$ & $2.96 \pm 0.16^{\mathrm{a}, \mathrm{d}}$ & $98.47 \pm 0.39^{\mathrm{b}}$ & $2.98 \pm 0.06^{\mathrm{a}, \mathrm{c}}$ \\
\hline & 40 & $64.59 \pm 0.23^{\mathrm{b}, \mathrm{c}}$ & $1.5 \pm 0.021^{\mathrm{c}, \mathrm{d}}$ & $65.54 \pm 2.38^{\mathrm{a}, \mathrm{b}}$ & $1.65 \pm 0.03^{\mathrm{a}, \mathrm{d}}$ & $66.68 \pm 2.14^{\mathrm{b}}$ & $1.69 \pm 0.07^{\mathrm{a}, \mathrm{c}}$ \\
\hline & 30 & $54.84+1.75^{\mathrm{b}, \mathrm{c}}$ & $1.39 \pm 0.56^{\mathrm{c}, \mathrm{d}}$ & $60.15 \pm 2.16^{\mathrm{a}, \mathrm{b}}$ & $1.45 \pm 0.01^{\mathrm{a}, \mathrm{d}}$ & $61.36 \pm 2.04^{\mathrm{c}, \mathrm{d}}$ & $1.52 \pm 0.32^{\mathrm{a}, \mathrm{c}}$ \\
\hline \multirow{3}{*}{0.05} & 50 & $60.94 \pm 1.96^{\mathrm{b}, \mathrm{c}}$ & $1.37 \pm 0.01^{\mathrm{a}, \mathrm{b}}$ & $66.29 \pm 2.20^{b}$ & $1.35 \pm 0.02^{\mathrm{a}, \mathrm{b}}$ & $77.68 \pm 1.16^{\mathrm{c}}$ & $2.21 \pm 0.10^{\mathrm{a}, \mathrm{b}}$ \\
\hline & 40 & $60.09 \pm 2.11^{\mathrm{b}, \mathrm{c}}$ & $1.3 \pm 0.01^{\mathrm{a}, \mathrm{b}}$ & $65.68 \pm 1.93^{\mathrm{c}, \mathrm{d}}$ & $1.32 \pm 0.02^{\mathrm{a}, \mathrm{d}}$ & $66.59 \pm 2.02^{\mathrm{c}}$ & $1.41 \pm 0.05^{\mathrm{c}, \mathrm{d}}$ \\
\hline & 30 & $50.08 \pm 1.63^{\mathrm{b}, \mathrm{c}}$ & $1.17 \pm 0.04^{\mathrm{a}, \mathrm{b}}$ & $62.43 \pm 2.41^{\mathrm{c}, \mathrm{d}}$ & $1.29 \pm 0.04^{\mathrm{a}, \mathrm{d}}$ & $65.23 \pm 1.93^{\mathrm{a}}$ & $1.37 \pm 0.08^{\mathrm{c}, \mathrm{d}}$ \\
\hline \multirow{3}{*}{$\begin{array}{c}\text { Enzyme } \\
\text { Concentration } \\
(\%)\end{array}$} & \multirow{3}{*}{$\begin{array}{c}\text { Temp } \\
\left({ }^{\circ} \mathrm{C}\right)\end{array}$} & \multicolumn{6}{|c|}{ PEPSIN } \\
\hline & & \multicolumn{2}{|c|}{$60 \mathrm{~min}$} & \multicolumn{2}{|c|}{$90 \mathrm{~min}$} & \multicolumn{2}{|c|}{$120 \mathrm{~min}$} \\
\hline & & $\begin{array}{c}\text { Degree of } \\
\text { hydrolysis (\%) }\end{array}$ & $\begin{array}{l}\text { Protein content } \\
(\mathrm{mg} / \mathrm{ml})\end{array}$ & $\begin{array}{c}\text { Degree of } \\
\text { hydrolysis (\%) }\end{array}$ & $\begin{array}{l}\text { Protein content } \\
(\mathrm{mg} / \mathrm{ml})\end{array}$ & $\begin{array}{c}\text { Degree of } \\
\text { hydrolysis (\%) }\end{array}$ & $\begin{array}{c}\text { Protein content } \\
(\mathrm{mg} / \mathrm{ml})\end{array}$ \\
\hline \multirow{3}{*}{0.15} & 50 & $74.22 \pm 1.89^{\mathrm{c}, \mathrm{d}}$ & $1.68 \pm 0.07^{\mathrm{a}, \mathrm{c}}$ & $78.16 \pm 0.90^{\mathrm{b}}$ & $1.83 \pm 0.06^{\mathrm{c}, \mathrm{d}}$ & $85.02 \pm 0.49^{c}$ & $2.01 \pm 0.07^{\mathrm{c}, \mathrm{d}}$ \\
\hline & 40 & $60.25 \pm 1.25^{\mathrm{b}}$ & $1.29 \pm 0.04^{\mathrm{a}, \mathrm{c}}$ & $72.70 \pm 1.67^{b}$ & $1.02 \pm 0.02^{\mathrm{c}, \mathrm{d}}$ & $83.1 \pm 1.97^{\mathrm{a}, \mathrm{d}}$ & $1.52 \pm 0.05^{\mathrm{c}, \mathrm{d}}$ \\
\hline & 30 & $55.63 \pm 0.88^{b}$ & $1.25 \pm 0.15^{\mathrm{a}, \mathrm{c}}$ & $72.62 \pm 1.59^{b}$ & $1.0 \pm 0.012^{\mathrm{c}, \mathrm{d}}$ & $60.46 \pm 1.66^{c}$ & $1.32 \pm 0.01^{\mathrm{c}, \mathrm{d}}$ \\
\hline \multirow{3}{*}{0.10} & 50 & $64.31 \pm 2.16^{b}$ & $1.15 \pm 0.01^{\mathrm{b}}$ & $75.01 \pm 1.57^{\mathrm{d}}$ & $1.29 \pm 0.04^{\mathrm{b}, \mathrm{c}}$ & $78.37 \pm 1.37^{b}$ & $1.52 \pm 0.021^{\mathrm{c}, \mathrm{d}}$ \\
\hline & 40 & $54.53 \pm 1.89^{\mathrm{b}}$ & $0.93 \pm 0.13^{\mathrm{b}}$ & $62.45 \pm 2.23^{\mathrm{d}}$ & $0.81 \pm 0.01^{\mathrm{b}, \mathrm{c}}$ & $70.25 \pm 0.05^{\mathrm{b}}$ & $1.45 \pm 0.03^{\mathrm{c}, \mathrm{d}}$ \\
\hline & 30 & $50.72 \pm 2.08^{\mathrm{c}, \mathrm{d}}$ & $0.79 \pm 0.05^{\mathrm{b}}$ & $54.52 \pm 1.70^{\mathrm{d}}$ & $0.65 \pm 0.01^{\mathrm{b}, \mathrm{c}}$ & $54.72 \pm 2.06^{b}$ & $0.69 \pm 0.02^{\mathrm{a}, \mathrm{d}}$ \\
\hline \multirow{3}{*}{0.05} & 50 & $62.98 \pm 1.75^{\mathrm{a}, \mathrm{b}}$ & $0.63 \pm 0.02^{\mathrm{c}, \mathrm{d}}$ & $72.26 \pm 1.67^{\mathrm{b}, \mathrm{c}}$ & $0.77 \pm 0.05^{\mathrm{b}, \mathrm{c}}$ & $77.19 \pm 2.05^{\mathrm{d}}$ & $1.12 \pm 0.01^{\mathrm{a}, \mathrm{d}}$ \\
\hline & 40 & $60.37 \pm 1.80^{\mathrm{a}, \mathrm{b}}$ & $0.61 \pm 0.01^{\mathrm{c}, \mathrm{d}}$ & $65.87 \pm 0.82^{\mathrm{b}, \mathrm{c}}$ & $0.64 \pm 0.01^{b, c}$ & $72.39 \pm 2.20^{\mathrm{d}}$ & $1.09 \pm 0.03^{\mathrm{a}, \mathrm{d}}$ \\
\hline & 30 & $56.57 \pm 2.11^{\mathrm{a}, \mathrm{b}}$ & $0.55 \pm 0.05^{\mathrm{c}, \mathrm{d}}$ & $61.39 \pm 2.49^{\mathrm{b}, \mathrm{c}}$ & $0.59 \pm 0.02^{\mathrm{b}, \mathrm{c}}$ & $61.46 \pm 2.30^{\mathrm{d}}$ & $0.87 \pm 0.01^{\mathrm{a}, \mathrm{d}}$ \\
\hline
\end{tabular}


Table 5. Continued...

\begin{tabular}{|c|c|c|c|c|c|c|c|}
\hline \multirow{3}{*}{$\begin{array}{c}\text { Enzyme } \\
\text { Concentration } \\
(\%)\end{array}$} & \multirow{3}{*}{$\begin{array}{l}\text { Temp } \\
\left({ }^{\circ} \mathbf{C}\right)\end{array}$} & \multicolumn{6}{|c|}{ TRYPSIN } \\
\hline & & \multicolumn{2}{|c|}{$60 \mathrm{~min}$} & \multicolumn{2}{|c|}{$90 \mathrm{~min}$} & \multicolumn{2}{|c|}{$120 \mathrm{~min}$} \\
\hline & & $\begin{array}{c}\text { Degree of } \\
\text { hydrolysis (\%) }\end{array}$ & $\begin{array}{l}\text { Protein content } \\
(\mathrm{mg} / \mathrm{ml})\end{array}$ & $\begin{array}{c}\text { Degree of } \\
\text { hydrolysis (\%) }\end{array}$ & $\begin{array}{l}\text { Protein content } \\
(\mathrm{mg} / \mathrm{ml})\end{array}$ & $\begin{array}{c}\text { Degree of } \\
\text { hydrolysis (\%) }\end{array}$ & $\begin{array}{c}\text { Protein content } \\
(\mathrm{mg} / \mathrm{ml})\end{array}$ \\
\hline \multirow{3}{*}{0.15} & 50 & $53.21 \pm 2.05$ & $1.35 \pm 0.026$ & $56.48 \pm 1.69^{\mathrm{b}}$ & $1.35 \pm 0.03^{\mathrm{d}}$ & $65.35 \pm 1.72^{\mathrm{d}}$ & $1.65 \pm 0.03^{\mathrm{b}, \mathrm{d}}$ \\
\hline & 40 & $31.66 \pm 1.73$ & $1.05 \pm 0.022$ & $47.32 \pm 1.90^{\mathrm{b}}$ & $1.2 \pm 0.01^{\mathrm{d}}$ & $49.31 \pm 1.71^{\mathrm{d}}$ & $1.25 \pm 0.28^{\mathrm{b}, \mathrm{d}}$ \\
\hline & 30 & $12.42 \pm 1.96$ & $0.59 \pm 0.06$ & $16.53 \pm 2.22^{\mathrm{b}}$ & $0.9 \pm 0.33^{\mathrm{d}}$ & $32.33 \pm 2.05^{\mathrm{d}}$ & $1.15 \pm 0.03^{\mathrm{b}, \mathrm{d}}$ \\
\hline \multirow{3}{*}{0.10} & 50 & $21.67 \pm 2.24^{\mathrm{b}, \mathrm{c}}$ & $0.75 \pm 0.05^{\mathrm{a}, \mathrm{d}}$ & $30.41 \pm 1.68^{\mathrm{d}}$ & $0.79 \pm 0.05^{\mathrm{c}, \mathrm{d}}$ & $60.64 \pm 1.56^{\mathrm{b}}$ & $1.09 \pm 0.02^{\mathrm{c}}$ \\
\hline & 40 & $15.63 \pm 2.04^{\mathrm{b}, \mathrm{c}}$ & $0.72 \pm 0.01^{\mathrm{a}, \mathrm{d}}$ & $18.63 \pm 2.16^{\mathrm{d}}$ & $0.77 \pm 0.06^{\mathrm{c}, \mathrm{d}}$ & $25.53 \pm 1.83^{\mathrm{b}}$ & $0.96 \pm 0.06^{c}$ \\
\hline & 30 & $10.31 \pm 2.57^{\mathrm{b}, \mathrm{c}}$ & $0.43 \pm 0.04^{\mathrm{a}, \mathrm{d}}$ & $15.63 \pm 1.93^{\mathrm{d}}$ & $0.45 \pm 0.08^{\mathrm{c}, \mathrm{d}}$ & $24.76 \pm 0.54^{\mathrm{b}}$ & $0.93 \pm 0.17^{c}$ \\
\hline \multirow{3}{*}{0.05} & 50 & $7.75 \pm 2.23^{\mathrm{c}, \mathrm{d}}$ & $0.43 \pm 0.04^{\mathrm{b}, \mathrm{c}}$ & $8.38 \pm 1.66^{\mathrm{b}, \mathrm{c}}$ & $0.57 \pm 0.04^{\mathrm{b}, \mathrm{c}}$ & $9.33 \pm 2.05^{\mathrm{a}, \mathrm{d}}$ & $0.79 \pm 0.05^{\mathrm{b}, \mathrm{c}}$ \\
\hline & 40 & $5.63 \pm 1.93^{\mathrm{c}, \mathrm{d}}$ & $0.34 \pm 0.06^{\mathrm{b}, \mathrm{c}}$ & $6.31 \pm 2.57^{\mathrm{b}, \mathrm{c}}$ & $0.37 \pm 0.01^{\mathrm{b}, \mathrm{c}}$ & $9.28 \pm 1.81^{\mathrm{a}, \mathrm{d}}$ & $0.64 \pm 0.03^{\mathrm{b}, \mathrm{c}}$ \\
\hline & 30 & $4.29 \pm 1.12^{\mathrm{c}, \mathrm{d}}$ & $0.25 \pm 0.07^{\mathrm{b}, \mathrm{c}}$ & $4.88 \pm 1.96^{\mathrm{b}, \mathrm{c}}$ & $0.31 \pm 0.04^{\mathrm{b}, \mathrm{c}}$ & $7.8 \pm 2.06^{\mathrm{a}, \mathrm{d}}$ & $0.59 \pm 0.06^{\mathrm{b}, \mathrm{c}}$ \\
\hline
\end{tabular}

Sample evaluation was done in triplicate. Values are calculated as Mean \pm SD $(n=3)$. Lowercase letters indicated significant differences $(p \leq 0.05)$. Values followed by the same letter were not significantly different $(p \leq 0.05)$.

\subsection{Functional properties}

Since MPH obtained from $P$. ostreatus using proteinase $\mathrm{K}$ at $0.15 \%$ concentration, at $50{ }^{\circ} \mathrm{C}$ for 120 minutes of hydrolysis period exhibited highest \%DH and maximum protein content, evaluation of functional properties was carried out with this protein hydrolysate and compared those with that of unhydrolsed P. ostreatus (UMP).

To our knowledge, the current work for the first time evaluated the effect of DH on different functional properties of MPHs obtained from P. ostreatus and represented in Table 6.

\subsubsection{Emulsifying properties}

The EAI is the area of oil/water interface stabilized per unit weight of protein and ESI is defined as time needed to achieve a turbidity of the emulsion that is one-half of its original value (Aryee et al., 2018; Chatterjee et al., 2015). Both the EAI and ESI mainly depend on the diffusion of the peptides at oil- water interfaces which stabilize the interface and this stabilization depends on the whole ionic character of the peptides (Chatterjee et al., 2015). The emulsifying capacity, which is based on surface properties of protein hydrolysates, describes how these hydrolysates effectively lower the interfacial tension between the hydrophobic and hydrophilic component in food (Amiza et al., 2012). Emulsifying properties in terms of EAI and ESI of unhydrolysed and proteinase K treated MPH were represented in Table 6 indicating that ESI significantly increased in proteinase K treated MPH as compared to UMP. According to Taha and Ibrahim, diffusion of peptide molecules into the interfaces was facilitated by degree of hydrolysis (Taha \& Ibrahim, 2002). According to Vodjdani and Whitaker, 1986, functional properties of protein hydrolysates are also influenced by the specificity of enzyme, the physical and chemical nature of intact protein, and hydrolysis conditions (Kester \& Richardson, 1984). Here we have used the very specific proteolytic enzyme for hydrolysis, i.e., proteinase $\mathrm{k}$, this might cause behind the good emulsifying capacity of MPHs. Hydrophilic and hydrophobic groups in the peptides stabilized oil-water interface which caused an increase in emulsifying property. Table 6 indicated that ESI significantly increased in case with Proteinase K treated MPH rather than UMP and EAI values were higher in both UMP and proteinase K treated MPH in the immediately sampled emulsion formation. This might have been due to the non-specific hydrophobic interaction and the orientation of the molecules at the oil-water interface of the formed emulsion which assisted in reducing the surface tension of the emulsion. Higher DH of hydrolysis denotes cleavage of more peptide bonds and release of free amino acids in the emulsion rendering enhanced surface 4 thus causing higher functional properties. 
It was also observed that for both the UMP and proteinase K treated MPH, EAI was more significant in the immediately sampled emulsion $\left(\mathrm{UMP}_{0}\right.$ and $\mathrm{MPHK}_{0}$ for untreated and proteinase $\mathrm{K}$ treated MPHs, respectively) than 10 minutes after the emulsion formation $\left(\mathrm{UMP}_{10}\right.$ and $\mathrm{MPHK}_{10}$ for untreated and proteinase K treated MPHs, respectively). Similar results were also observed by Chatterjee et al., 2015 who reported that papain, pepsin and alcalase treated sesame protein hydrolysates were of improved EAI and ESI. Our results are in line with the previous findings (Amiza et al., 2012) reporting that cobia protein hydrolysate produced the most stable foam after 60 minutes of whipping with $96 \%$ hydrolysis. The foaming capability of Cobia protein hydrolysate at DH of $96 \%$ after 60 min was $113.3 \%$ and most stable among others, i.e., DH $53 \%$ and DH $71 \%$ (Amiza et al., 2012). In another study, EAI of High-pressure jet processed skim milk from 100 to $500 \mathrm{Mpa}$ varied from $6.5 \pm 0.7$ to $8.3 \pm 0.7 \%$ which was much lower than our report (Hettiarachchi et al., 2018).

\subsubsection{Foaming properties}

Foaming capacity and stability are indicators of whippability, hence widely demanded in food products like cake and whipping topping to develop products with better consistence and sensory property. In this study, both FS and FC of proteinase K treated MPH increased when compared with UMP. Highest FS was achieved after 10 minutes of whipping of sample extract which gradually decreased over time (Table 6). Ishara et al. evaluated functional properties of flour of button mushroom Agaricus bisporus and oyster mushroom $P$. ostreatus and reported that FC and FS of button flour was significantly higher than those of oyster (Ishara et al., 2018). Foaming stability of processed skimmed milk using high pressure jet from 200 to 500Mpa was approximately 55\% after $24 \mathrm{hr}$ (Harte et al., 2019) which was in agreement with our report of proteinase K treated MPH after 60 min of foam formation.

\subsubsection{Water holding capacity (WHC)}

The WHC is the quantity of water fixed per gram of sample (Bayar et al., 2017). In our study, WHC of powdered mushroom was determined to be about $88.7 \pm 3.25 \%$. According to Bayar et al. (2017) pectin extracted from Opuntia ficus indica (L.) Mill. through ultrasonication had $4.84 \mathrm{~g} / \mathrm{g}$ of WHC. Gul et al. compared water holding capacity of kefir using different milk starter culture of which buffalo milk kefir obtained maximum WHC (77.35 $\pm 0.6 \%)$ among others (Gul et al., 2018). WHC which has immense importance in food industries are influenced by several factors including particle size and porosity of samples, ionic strength of the solution, pH and temperature etc. (Bayar et al., 2017; Elleuch et al., 2011). High WHC of MPH in the current study indicated that it could be used in cake preparation to avoid syneresis.

\subsubsection{Oil holding capacity}

The OHC of proteinase $\mathrm{K}$ treated MPH in the present investigation was $54.26 \pm 0.21 \%$ and due to this high OHC, MPH of $P$. ostreatus may be used for the preparation of cake, mayonnaise, salad dressings especially in regard of better flavor retention, extended shelf life and preventing food from oxidative rancidity. In another study conducted by Cruz-solorio et al., they also investigated that OHC of protein concentration of 3 strains of $P$. ostreatus ( $\mathrm{PCM}$, POS and $\mathrm{PCM} \times \mathrm{POM}$ ) was higher than wheat flour (CruzSolorio et al., 2018). Protein concentrates of these $P$. ostreatus strains showed significantly higher values than wheat flour and their corresponding wheat flour, i.e., 173.3 for protein concentrate of PCM against 122.2 for PCM flour, 214.1 for protein concentrate of POS against 125.9 for POS flour, 195.8 for protein concentrate of $\mathrm{PCM} \times \mathrm{POS}$ and 104.8 for $\mathrm{PCM} \times \mathrm{POS}$ flour; while the $\mathrm{OHC}$ for wheat flour was lowest, i.e., $94.9 \%$ among all of these. Maqsood et al. reported that, $180.39 \%$ of $\mathrm{OHC}$ of cow milk protein and for camel milk protein ranged from 161.77 to $181.12 \%$ (Maqsood et al., 2019). The OHC is a parameter having high 
Optimization of enzymatic hydrolysis of Pleurotus ostreatus derived proteins through RSM and evaluation of nutritional and functional qualities of mushroom protein hydrolysates

Goswami, B. et al.

importance in food industries and it can be influenced by various factors as the overall charge density and the hydrophilic character of constituents (Elleuch et al., 2011).

Table 6. Emulsifying properties and Foaming properties of UMP and MPHs (P. ostreatus).

\begin{tabular}{|c|c|c|c|c|c|}
\hline \multirow{2}{*}{ Samples } & \multicolumn{2}{|c|}{ Emulsifying Properties } & \multirow{2}{*}{ Samples } & \multicolumn{2}{|c|}{ Foaming Properties } \\
\hline & $\operatorname{EAI}\left(\mathrm{m}^{2} / \mathrm{g}\right)$ & ESI (min) & & FC (\%) & FS (\%) \\
\hline IIMD & $7105+230$ & \multirow{4}{*}{$22.81 \pm 1.47$} & $\mathrm{UMP}_{10}$ & $390 \pm 42.43^{* *}$ & $95 \pm 7.07 * *$ \\
\hline UIVIr 0 & ס & & $\mathrm{UMP}_{30}$ & $290 \pm 14.14 * *$ & $72.5 \pm 3.53 * *$ \\
\hline \multirow{2}{*}{$\mathrm{UMP}_{10}$} & \multirow{2}{*}{$39.85 \pm 3.69$} & & $\mathrm{UMP}_{45}$ & $170 \pm 42.42 * *$ & $37.5 \pm 17.67 * *$ \\
\hline & & & $\mathrm{UMP}_{60}$ & $50 \pm 14.14^{* *}$ & $12.5 \pm 3.53 * *$ \\
\hline \multirow{2}{*}{$\mathrm{MPHK}_{0}$} & \multirow{2}{*}{$28.18 \pm 0.54$} & \multirow{4}{*}{$136 \pm 36.49$} & $\mathrm{MPHK}_{10}$ & $580 \pm 14.14^{* *}$ & $145 \pm 3.53 * *$ \\
\hline & & & $\mathrm{MPHK}_{30}$ & $370 \pm 14.14 * *$ & $92.5 \pm 3.53 * *$ \\
\hline \multirow{2}{*}{$\mathrm{MPHK}_{10}$} & \multirow{2}{*}{$25.98 \pm 0.90$} & & $\mathrm{MPHK}_{45}$ & $280 \pm 28.29 * *$ & $70 \pm 7.07 * *$ \\
\hline & & & $\mathrm{MPHK}_{60}$ & $220 \pm 28.28 * *$ & $55 \pm 7.07 * *$ \\
\hline
\end{tabular}

$\mathrm{UMP}_{0}, \mathrm{UMP}_{10}, \mathrm{UMP}_{30}, \mathrm{UMP}_{45}$ and $\mathrm{UMP}_{60}=$ Unhydrolysed mushroom immediately sampled and sampled after 10, 30, 45 and 60 min respectively. $\mathrm{MPHK}_{0}, \mathrm{MPHK}_{10}, \mathrm{MPHK}_{30}, \mathrm{MPHK}_{45}, \mathrm{MPHK}_{60}=$ Proteinase $\mathrm{K}$ treated Mushroom protein hydrolysate with $99.42 \%$ of Degree of hydrolysis immediately sampled and sampled after 10,30,45 and 60 min respectively. Sample evaluation was done in triplicate. Values are calculated as Mean $\pm \mathrm{SD}(\mathrm{n}=3) . * *$ indicates values of significantly different $(p \leq 0.01)$.

\section{Conclusion}

The results indicated that $P$. ostreatus cultivated on paddy straw had good protein and ash content with antinutritional factors below the threshold limits. In the present study hydrolysis of this oyster mushroom using three different proteolytic enzymes yielded mushroom protein hydrolysates with favorably higher degree of hydrolysis. The entire experimental results showed that proteinase $\mathrm{k}$ treated mushroom protein hydrolysate contains enhanced functional properties which may be a potential option for food formulation.

\section{References}

Adeduntan, S. A. (2014). Nutritional and anti nutritional characteristics of some dominant fungi species in South Western Nigeria. International Journal of Engineering Science, 3, 18-24.

Adler-Nissen, J. (1986). Enzymic hydrolysis of food proteins. New York: Elsevier Applied Science Publishers.

Association of Official Analytical Chemists - AOAC (1980). Official Method of Analysis (13th edn). Washington: Association of Official Analytical Chemists.

Ahlawat, O., \& Tewari, R. (2007). Cultivation technology of paddy straw mushroom (Volvariella volvacea) (Vol. 36). India: National Research Centre for Mushroom.

Akwaowo, E. U., Ndon, B. A., \& Etuk, E. U. (2000). Minerals and antinutrients in fluted pumpkin (Telfairia occidentalis Hook $f$.). Food Chemistry, 70(2), 235-240. http://dx.doi.org/10.1016/S0308-8146(99)00207-1

Aletor, V. A. (1995). Compositional studies on edible tropical species of mushrooms. Food Chemistry, 54(3), 265-268. http://dx.doi.org/10.1016/0308-8146(95)00044-J

Amiza, M., Kong, Y., \& Faazaz, A. (2012). Effects of degree of hydrolysis on physicochemical properties of Cobia (Rachycentron canadum) frame hydrolysate. International Food Research Journal, 19(1), 199-206.

Aryee, A., Agyei, D., \& Udenigwe, C. (2018). Impact of processing on the chemistry and functionality of food proteins. In R. Y. Yada (Ed.), Proteins in food processing (pp. 27-45). Oxford: Elsevier. . http://dx.doi.org/10.1016/B978-0-08-100722-8.00003-6.

Barmina, I., Lickrastina, A., Valdmanis, R., Zake, M., Arshanitsa, A., Solodovnik, V., \& Telysheva, G. (2013). Effects of biomass composition variations on gasification and combustion characteristics. Engineering for Rural Development, 5, $23-24$.

Bayar, N., Bouallegue, T., Achour, M., Kriaa, M., Bougatef, A., \& Kammoun, R. (2017). Ultrasonic extraction of pectin from Opuntia ficus indica cladodes after mucilage removal: Optimization of experimental conditions and evaluation of chemical and functional properties. Food Chemistry, 235, 275-282. PMid:28554636. http://dx.doi.org/10.1016/j.foodchem.2017.05.029

Chatterjee, R., Dey, T. K., Ghosh, M., \& Dhar, P. (2015). Enzymatic modification of sesame seed protein, sourced from waste resource for nutraceutical application. Food and Bioproducts Processing, 94, 70-81. http://dx.doi.org/10.1016/j.fbp.2015.01.007

Chaturvedi, V. K., Agarwal, S., Gupta, K. K., Ramteke, P. W., \& Singh, M. (2018). Medicinal mushroom: Boon for therapeutic applications. 3 Biotech, 8(8), 334. http://dx.doi.org/10.1007/s13205-018-1358-0 
Cruz-Solorio, A., Villanueva-Arce, R., Garín-Aguilar, M. E., Leal-Lara, H., \& Valencia-del Toro, G. (2018). Functional properties of flours and protein concentrates of 3 strains of the edible mushroom Pleurotus ostreatus. Journal of Food Science and Technology, 55(10), 3892-3901. PMid:30228387. http://dx.doi.org/10.1007/s13197-018-3312-x

Elleuch, M., Bedigian, D., Roiseux, O., Besbes, S., Blecker, C., \& Attia, H. (2011). Dietary fibre and fibre-rich by-products of food processing: Characterisation, technological functionality and commercial applications: A review. Food Chemistry, 124(2), 411-421. http://dx.doi.org/10.1016/j.foodchem.2010.06.077

Erjavec, J., Kos, J., Ravnikar, M., Dreo, T., \& Sabotič, J. (2012). Proteins of higher fungi: From forest to application. Trends in Biotechnology, 30(5), 259-273. PMid:22341093. http://dx.doi.org/10.1016/j.tibtech.2012.01.004

Gąsecka, M., Mleczek, M., Siwulski, M., \& Niedzielski, P. (2016). Phenolic composition and antioxidant properties of Pleurotus ostreatus and Pleurotus eryngii enriched with selenium and zinc. European Food Research and Technology, 242(5), 723-732. http://dx.doi.org/10.1007/s00217-015-2580-1

Gaur, T., Rao, P., \& Kushwaha, K. (2016). Nutritional and anti-nutritional components of some selected edible mushroom species. Indian Journal of Natural Products and Resources, 7(2), 155-161.

Godwin, O. O. (2015). Proximate and Antinutrient Content of Pleurotus ostreatus (Jacq.) P. Kumm Found In Akwa Ibom State, Nigeria.

Golak-Siwulska, I., Kałużewicz, A., Spiżewski, T., Siwulski, M., \& Sobieralski, K. (2018). Bioactive compounds and medicinal properties of Oyster mushrooms (Pleurotus sp.). Folia Horticulturae, 30(2), 191-201. http://dx.doi.org/10.2478/fhort-2018-0012

González, A., Nobre, C., Simões, L. S., Cruz, M., Loredo, A., Rodríguez-Jasso, R. M., Contreras, J., Texeira, J., \& Belmares, R. (2021). Evaluation of functional and nutritional potential of a protein concentrate from Pleurotus ostreatus mushroom. Food Chemistry, 346, 128884. PMid:33401088. http://dx.doi.org/10.1016/j.foodchem.2020.128884

Goswami, B., \& Bhowal, J. (2015). Optimization of parameters for production of protein hydrolysate using edible oyster mushroom (Pleurotus ostreatus). Journal of Food Processing \& Technology, 6, 8. http://dx.doi.org/10.4172/2157-7110.S1.023

Greeshma, A., \& Sridhar, K. (2018). Functional attributes of ethnically edible ectomycorrhizal wild mushroom Amanita in India. Microbial Biosystems, 3(1), 34-44. http://dx.doi.org/10.21608/mb.2018.12358

Gul, O., Atalar, I., Mortas, M., \& Dervisoglu, M. (2018). Rheological, textural, colour and sensorial properties of kefir produced with buffalo milk using kefir grains and starter culture: A comparison with cows' milk kefir. International Journal of Dairy Technology, 71, 73-80. http://dx.doi.org/10.1111/1471-0307.12503

Harte, F. M., Martinez, M. C., \& Mohan, M. S. (2019). Foaming and emulsifying properties of high pressure jet processing pasteurized milk. US Pat. No. 0,374,359. Pennsylvania: Penn State Research Foundation.

Hettiarachchi, C. A., Corzo-Martínez, M., Mohan, M. S., \& Harte, F. M. (2018). Enhanced foaming and emulsifying properties of high-pressure-jet-processed skim milk. International Dairy Journal, 87, 60-66. http://dx.doi.org/10.1016/j.idairyj.2018.06.004

Hoa, H. T., Wang, C.-L., \& Wang, C.-H. (2015). The effects of different substrates on the growth, yield, and nutritional composition of two oyster mushrooms (Pleurotus ostreatus and Pleurotus cystidiosus). Mycobiology, 43(4), 423-434. PMid:26839502. http://dx.doi.org/10.5941/MYCO.2015.43.4.423

ljioma Blessing, C., Ihediohanma Ngozi, C., Onuegbu Ngozi, C., \& Okafor Damaris, C. (2015). Nutritional composition and some anti-nutritional factors of three edible mushroom species in South Eastern Nigeria. European Journal of Food Science and Technology, 3(2), 57-63.

Ishara, J. R., Sila, D. N., Kenji, G. M., \& Buzera, A. K. (2018). Nutritional and functional properties of mushroom (Agaricus bisporus \& Pleurotus ostreatus) and their blends with maize flour. American Journal of Food Science and Technology, 6(1), 3341. http://dx.doi.org/10.12691/ajfst-6-1-6

Jamdar, S., Rajalakshmi, V., Pednekar, M., Juan, F., Yardi, V., \& Sharma, A. (2010). Influence of degree of hydrolysis on functional properties, antioxidant activity and ACE inhibitory activity of peanut protein hydrolysate. Food Chemistry, 121(1), 178184. http://dx.doi.org/10.1016/j.foodchem.2009.12.027

Josiane, M., Estelle, M., \& Francis, N. (2018). Effect of substrates on nutritional composition and functional properties of Pleurotus ostreatus. Current Research in Agricultural Sciences, 5(1), 15-22.

Kadiri, M. (1990). Physiological studies on some Nigerian mushrooms. Nigeria: University of Ibadan.

Kester, J., \& Richardson, T. (1984). Modification of whey proteins to improve functionality. Journal of Dairy Science, 67(11), 2757-2774. http://dx.doi.org/10.3168/jds.S0022-0302(84)81633-1

Kirbag, S., \& Akyuz, M. (2008). Effect of various agro-residues on growing periods, yield and biological efficiency of Pleurotus eryngii. Journal of Food Agriculture and Environment, 6, 402-405.

Latta, M., \& Eskin, M. (1980). A simple and rapid colorimetric method for phytate determination. Journal of Agricultural and Food Chemistry, 28(6), 1313-1315. http://dx.doi.org/10.1021/jf60232a049

Lavelli, V., Proserpio, C., Gallotti, F., Laureati, M., \& Pagliarini, E. (2018). Circular reuse of bio-resources: The role of Pleurotus spp. in the development of functional foods. Food \& Function, 9(3), 1353-1372. PMid:29480298. http://dx.doi.org/10.1039/C7FO01747B

Liu, B.-L., \& Chiang, P.-S. (2008). Production of hydrolysate with antioxidative activity and functional properties by enzymatic hydrolysis of defatted sesame (Sesamum indicum L.). International Journal of Applied Science and Engineering, 6(2), 73-83.

Lowry, O. H., Rosebrough, N. J., Farr, A. L., \& Randall, R. J. (1951). Protein measurement with the Folin phenol reagent. The Journal of Biological Chemistry, 193(1), 265-275. PMid:14907713. http://dx.doi.org/10.1016/S0021-9258(19)52451-6

Maqsood, S., Al-Dowaila, A., Mudgil, P., Kamal, H., Jobe, B., \& Hassan, H. M. (2019). Comparative characterization of protein and lipid fractions from camel and cow milk, their functionality, antioxidant and antihypertensive properties upon simulated gastro-intestinal digestion. Food Chemistry, 279, 328-338. PMid:30611498. http://dx.doi.org/10.1016/j.foodchem.2018.12.011 
Optimization of enzymatic hydrolysis of Pleurotus ostreatus derived proteins through RSM and evaluation of nutritional and functional qualities of mushroom protein hydrolysates

Goswami, B. et al.

McCarthy, A. L., O'Callaghan, Y. C., \& O'Brien, N. M. (2013). Protein hydrolysates from agricultural crops: Bioactivity and potential for functional food development. Agriculture, 3(1), 112-130. http://dx.doi.org/10.3390/agriculture3010112

Miles, P. G., \& Chang, S.-T. (2004). Mushrooms: Cultivation, nutritional value, medicinal effect, and environmental impact. Boca Raton: CRC Press. . http://dx.doi.org/10.1201/9780203492086.

Narh, M. D. L., Addo, P., Dzomeku, M., \& Obodai, M. (2018). Bioprospecting of powdered pineapple rind as an organic supplement of composted sawdust for Pleurotus ostreatus mushroom cultivation. Food Science \& Nutrition, 6(2), 280-286. PMid:29564093. http://dx.doi.org/10.1002/fsn3.551

Nielsen, P., Petersen, D., \& Dambmann, C. (2001). Improved method for determining food protein degree of hydrolysis. Journal of Food Science, 66(5), 642-646. http://dx.doi.org/10.1111/j.1365-2621.2001.tb04614.x

Ogundele, G., Salawu, S., Abdulraheem, I., \& Bamidele, O. (2017). Nutritional composition of oyster mushroom (Pleurotus ostreatus) grown on softwood (Daniella oliveri) sawdust and hardwood (Anogeissus leiocarpus) sawdust. Current Journal of Applied Science and Technology, 20(1), 1-7.

Okwu, D., \& Ndu, C. (2006). Evaluation of the phytonutrients, mineral and vitamin contents of some varieties of yam (Dioscorea sp.). International Journal of Molecular Medicine and Advanced Sciences, 2(2), 199-203.

Oly-Alawuba, N., \& Obiakor-Okeke, P. (2014). Antinutrient profile of three mushroom varieties consumed in Amaifeke, Orlu, Imo state. Food Science and Quality Management, 32, 1-5.

Onuoha, C., Uchechi, U., \& Onuoha, B. (2009). Cultivation of Pleurotus pulmonarius (mushroom) using some agrowaste materials. Agricultural Journal, 4(2), 109-112.

Osagie, A. U., Eka, O. U., \& Igodan, V. O. (1998). Nutritional quality of plant foods. Benin: Post Harvest Research Unit, Dept. of Biochemistry, University of Benin.

Oyetayo, O. V., \& Ariyo, O. O. (2013). Micro and macronutrient properties of Pleurotus ostreatus (Jacq: Fries) cultivated on different wood substrates. Jordan Journal of Biological Sciences, 147(898), 1-4. http://dx.doi.org/10.12816/0001537

Park, K. H., Lee, E. S., Jin, Y. I., Myung, K. S., Park, H. W., Park, C. G., Kong, W. S., \& Kim, Y. O. (2016). Inhibitory effect of Panax ginseng and Pleurotus ostreatus complex on expression of cytokine genes induced by extract of Dermatophagoides pteronissinus in human monocytic THP-1 and EoL-1 cells. Journal of Mushroom, 14(4), 155-161. http://dx.doi.org/10.14480/JM.2016.14.4.155

Peter, O. E., Peter, G. R., Obele, I. I., Owuna, G., Danladi, M. M., Obiekieze, S., \& Akwashiki, O. (2019). Utilization of some agro-wastes for cultivation of Pleurotus ostreatus (Oyster Mushroom) in Keffi Nigeria. Environmental Microbiology, 5(2), 60-69.

Sánchez, C. (2009). Lignocellulosic residues: Biodegradation and bioconversion by fungi. Biotechnology Advances, 27(2), 185194. PMid:19100826. http://dx.doi.org/10.1016/j.biotechadv.2008.11.001

Sánchez, C. (2010). Cultivation of Pleurotus ostreatus and other edible mushrooms. Applied Microbiology and Biotechnology, 85(5), 1321-1337. PMid:19956947. http://dx.doi.org/10.1007/s00253-009-2343-7

Sangtitanu, T., Sangtanoo, P., Srimongkol, P., Saisavoey, T., Reamtong, O., \& Karnchanatat, A. (2020). Peptides obtained from edible mushrooms: Hericium erinaceus offers the ability to scavenge free radicals and induce apoptosis in lung cancer cells in humans. Food \& Function, 11(6), 4927-4939. PMid:32432266. http://dx.doi.org/10.1039/DOFO00227E

Schaafsma, G. (2009). Safety of protein hydrolysates, fractions thereof and bioactive peptides in human nutrition. European Journal of Clinical Nutrition, 63(10), 1161-1168. PMid:19623200. http://dx.doi.org/10.1038/ejcn.2009.56

Sujith, P., \& Hymavathi, T. (2011). Recent developments with debittering of protein hydrolysates. Asian Journal of Food and Agro-Industry, 4(6), 365-381.

Taha, F., \& Ibrahim, M. (2002). Effect of degree of hydrolysis on the functional properties of some oilseed proteins. Grasas $y$ Aceites, 53(3), 273-281. http://dx.doi.org/10.3989/gya.2002.v53.i3.317

Tolera, K. D., \& Abera, S. (2017). Nutritional quality of Oyster Mushroom (Pleurotus ostreatus) as affected by osmotic pretreatments and drying methods. Food Science \& Nutrition, 5(5), 989-996. PMid:28948016. http://dx.doi.org/10.1002/fsn3.484

Vaintraub, I. A., \& Lapteva, N. A. (1988). Colorimetric determination of phytate in unpurified extracts of seeds and the products of their processing. Analytical Biochemistry, 175(1), 227-230. PMid:3245569. http://dx.doi.org/10.1016/0003-2697(88)90382-X

Woldegiorgis, A., Abate, D., Haki, G., \& Ziegler, G. (2015). Major, minor and toxic minerals and anti-nutrients composition in edible mushrooms collected from Ethiopia. Journal of Food Processing \& Technology, 6(3), 1.

Yuan, B., Zhao, L., Rakariyatham, K., Han, Y., Gao, Z., Muinde Kimatu, B., Hu, Q., \& Xiao, H. (2017). Isolation of a novel bioactive protein from an edible mushroom Pleurotus eryngii and its anti-inflammatory potential. Food \& Function, 8(6), 21752183. PMid:28524200. http://dx.doi.org/10.1039/C7FO00244K

Zheng, X., Li, L., Liu, X., Wang, X., Lin, J., \& Li, D. (2006). Production of hydrolysate with antioxidative activity by enzymatic hydrolysis of extruded corn gluten. Applied Microbiology and Biotechnology, 73(4), 763-770. PMid:16977469.

http://dx.doi.org/10.1007/s00253-006-0537-9

Funding: None. 